\title{
Diastema size and type of upper lip midline frenulum attachment
}

\author{
A. Sękowska', R. Chałas² \\ ${ }^{1}$ Department of Jaw Orthopaedics, Medical University of Lublin, Poland \\ ${ }^{2}$ Department of Conservative Dentistry and Endodontics, Medical University of Lublin, Poland
}

[Received: 26 August 2016; Accepted: 25 October 2016]

Background: Diastema is a space between teeth. The most often is maxillary midline diastema between upper central incisors. One of the main causes of diastema is enlarged upper lip frenulum attachment. The aim of the study was to assess frenulum attachment in patients with diastema and investigate if type of upper lip frenulum attachment has an impact on the width of diastema.

Materials and methods: Upper lip frenulum attachment was assessed clinically in two groups of adult patients: study group with diastema and control group without diastema. Moreover the width of diastema was measured on plaster models of dentition. The results were statistically analysed.

Results: In study material the most often was diastema in range more than $2 \mathrm{~mm}$. There were statistically significant differences between study and control group in upper lip frenulum attachment $(p<0.05)$. Normal frenulum attachment (mucosal or gingival) was typical for group without diastema, but enlarged frenulum (papillary or papilla penetrating) was characteristic for diastema group. Type of frenulum had significant $(p<0.05)$ impact to the width of diastema. Small diastema $(\leq 2 \mathrm{~mm})$ more often coexisted with normal frenulum. Oversized frenulum was observed in the big diastema (> $2 \mathrm{~mm}$ ).

Conclusions: Patients with diastema have more often oversized upper lip frenulum attachment then patients without diastema. The most often type of frenulum in patients with diastema is papillary and papilla penetrating type. Type of upper lip frenulum attachment has an impact to the size of diastema. (Folia Morphol 2017; 76, 3: 501-505)

Key words: midline diastema, frenulum attachment

\section{INTRODUCTION}

Diastema is a space between teeth. In adults after permanent teeth eruption all spaces should be closed according to six keys of normal occlusion by Andrews [1]. But sometimes spaces are not closed and they are called diastemas or trems. The most frequent is maxillary midline diastema between upper central incisors. Prevalence of diastema in adults is between $3.7 \%$ [33] and $16.2 \%$ [8] and it depends on race. In blacks diastema is more frequent then in whites $[8,28]$. There are many causes of diastema. Attia [2] describes four general groups of diastema causes: 1. Dental defects, for example microdontia or hypodontia of teeth especially in upper lateral incisors $[6,31]$ or supernumerary teeth between upper central incisors especially mesiodens $[6,34] ; 2$. Periodontal defect, such as improper frenulum attachment $[4,6,11,17]$ or periodontal disease $[10,17,18]$; 3. Muscular defect such as large tongue $[15,19]$; 4. Neuromuscular defect - improper position of tongue during rest or function like swallowing or speech. Abnormal upper lip midline frenulum attachment is one of the most frequent described causes $[4,6,11,17]$.

Address for correspondence: R. Chałas, MD, PhD, Department of Conservative Dentistry and Endodontics, Medical University of Lublin, ul. Karmelicka 7, 20-081 Lublin, Poland, tel: + 488152879 20, e-mail: renata.chalas@umlub.pl 
Table 1. Sex of patients and size of diastema

\begin{tabular}{lccccccccc}
\hline Sex & $\mathbf{n}$ & $\mathbf{M}$ & $\mathbf{S D}$ & $\mathbf{V}[\%]$ & $\mathbf{M i n}$ & $\mathbf{0 1}$ & $\mathbf{M e}$ & $\mathbf{0 3}$ & Max \\
\hline Female & 41 & 2.20 & 0.90 & 40.95 & 0.34 & 1.76 & 2.16 & 2.94 & 3.64 \\
Male & 11 & 1.65 & 0.60 & 36.31 & 0.47 & 1.25 & 1.82 & 2.16 & 2.46 \\
Female + Male & 52 & 2.09 & 0.87 & 41.79 & 0.34 & 1.42 & 2.01 & 2.83 & 3.64 \\
\hline
\end{tabular}

Placek et al. [29] classified labial frenulum attachments in four types: I - mucosal attachment; II - gingival attachment; III — papillary attachment and; IV — papilla penetrating attachment. Mucosal and gingival types are the most popular [3, 11, 29] described as normal but papillary and papilla penetrating attachments as pathological. The type of frenulum is changed with age and it migrates nasally during growth and teeth eruption [12]. In adults mucosal or gingival types should be observed.

The aim of the study was to assess maxillary midline frenulum attachment in patients with diastema and compare with patients without diastema. Frenulum type for different size of diastema was also assessed.

\section{MATERIALS AND METHODS}

The study was approved by Bioethics Committee of the Medical University of Lublin (No.KE- 0254/29/2014). One hundred and two adult Caucasian patients with fully erupted permanent teeth (DS4M2 according to Björk et al. [7], where DS4 - Dental Stage 4 means fully erupted premolars and canines and $\mathrm{M} 2$ - fully erupted second molars) were examined. Patients were divided into two groups: study group $(n=52)$ with maxillary midline diastema and control group $(n=50)$ without diastema. Maxillary midline frenulum attachment was clinically assessed and classified according to Placek classification.

Plaster models of teeth of patients with diastema were made for measuring width of diastema. Measurements were made using digital calliper to the nearest $0.01 \mathrm{~mm}$. The width of diastema was measured in the largest width. The obtained measured width was divided into three groups: small diastema $\leq 1 \mathrm{~mm}$, medium $>1 \mathrm{~mm}$ and $\leq 2 \mathrm{~mm}$ and large diastema $>2 \mathrm{~mm}$. The results were statistically analysed using Pearson's $\chi^{2}$ tests.

\section{RESULTS}

The most patients were female $-78.8 \%$ in the study group and $86 \%$ in the control group. The mean age in patients with diastema was $23.28 \pm 7.14$ years and $21.68 \pm 6.08$ years in patients without diastema. The mean size of diastema was $2.09 \pm 0.87 \mathrm{~mm}$ and mean

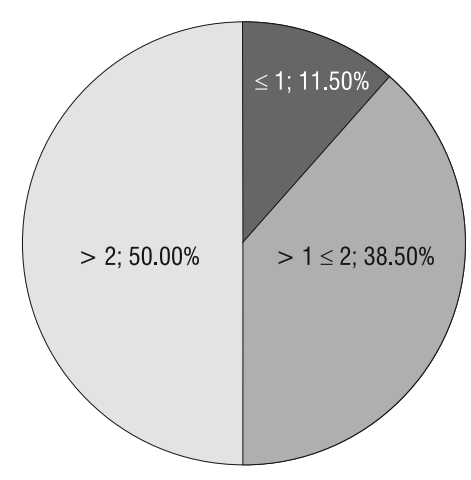

Figure 1. Patients (\%) in different range of width of diastema.

size for female was $2.20 \pm 0.9 \mathrm{~mm}$ and $1.65 \pm 0.60 \mathrm{~mm}$ for male (Table 1). Distribution of width ranges of diastema for both sexes were following: diastema width in the range $\leq 1 \mathrm{~mm}$ occurred in $11.5 \%$ of patients $(12.2 \%$ of female and $9.1 \%$ of male). Diastema width in the range of $1 \mathrm{~mm}$ to $2 \mathrm{~mm}$ inclusive was observed in $38.5 \%$ of patients (31.7\% female and $63.6 \%$ male). Diastema width in the range of greater than $2 \mathrm{~mm}$ was seen in $50.0 \%$ of patients (56.1\% female and $27.3 \%$ of male) (Fig. 1).

The analysis of the type of frenulum attachment showed statistically significant differences between the study and control groups ( $p<0.0001$; Table 2 ). The mucosal (I) type of frenulum attachment was observed in $17.3 \%$ with diastema and in $66 \%$ without diastema. The gingival (II) type was observed in $25 \%$ in the study group and in $32 \%$ in the control group. The papillary type (III) of frenulum occurrence was in $26.9 \%$ in patients with diastema and in only $2 \%$ without diastema. The papilla penetrating type (IV) was observed only in patients with diastema in $30.8 \%$ (Fig. 2).

Due to small group of patients with diastema width of $\leq 1 \mathrm{~mm}$, the measured widths of diastema have been divided into the following two groups for statistical analysis: I - width of diastema $\leq 2 \mathrm{~mm}$ (small diastema); II - width of diastema $>2 \mathrm{~mm}$ (large diastema).

Statistically significant correlation ( $p=0.002$ ) between type of frenulum and width of diastema 
Table 2. Diastema prevalence and type of frenulum attachment

\begin{tabular}{lccccc}
\hline Group & \multicolumn{3}{c}{ Type of frenulum attachment } & \multirow{2}{c}{$\begin{array}{c}\text { Chi-square test } \\
\text { of independence }\end{array}$} \\
\cline { 2 - 5 } & I & II & III & IV & \\
\hline Patients with diastema & $9(17.3 \%)$ & $13(25.0 \%)$ & $14(26.9 \%)$ & $16(30.8 \%)$ & $\chi^{2}=41.27$ \\
Patients without diastema & $33(66.0 \%)$ & $16(32.0 \%)$ & $1(2.0 \%)$ & $0(0.0 \%)$ & $\mathrm{p}<0.0001$ \\
\hline
\end{tabular}

Table 3. Diastema size and type of frenulum attachment

\begin{tabular}{lccccc}
\hline Width of diastema [mm] & \multicolumn{4}{c}{ Type of frenulum attachment } & \multirow{2}{c}{$\begin{array}{c}\text { Chi-square test } \\
\text { of independence }\end{array}$} \\
\cline { 2 - 5 } & I & II & III & IV & \\
\hline$\leq 2$ & $9(34.6 \%)$ & $8(30.8 \%)$ & $5(19.2 \%)$ & $4(15.4 \%)$ & $\chi^{2}=14.84$ \\
$>2$ & $0(0.0 \%)$ & $5(19.2 \%)$ & $9(34.6 \%)$ & $12(46.2 \%)$ & $\mathrm{p}=0.002$ \\
Total & $9(17.3 \%)$ & $13(25.0 \%)$ & $14(26.9 \%)$ & $16(30.8 \%)$ & - \\
\hline
\end{tabular}

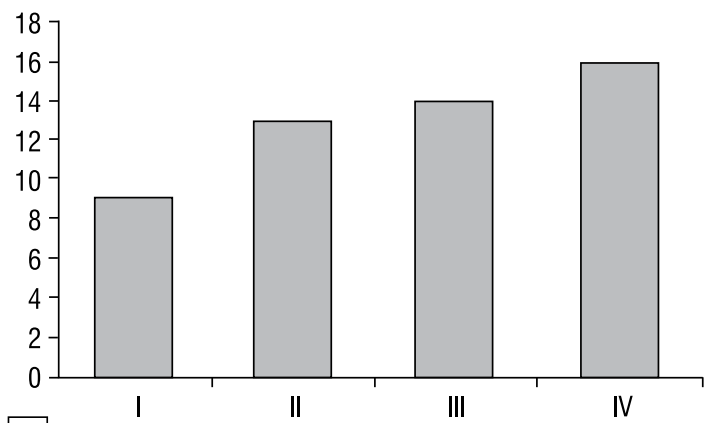

A Type of frenulum attachment

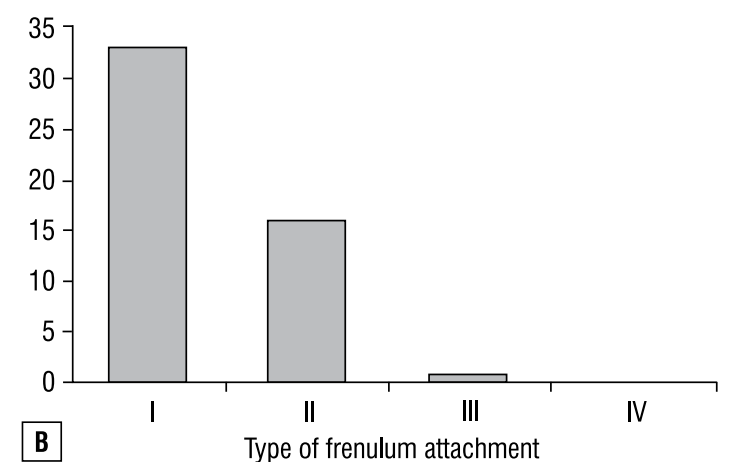

Figure 2. Type of frenulum in group with (A) and without (B) diastema.

was observed (Table 3). Type I - mucosal (34.6\%) and type II - gingival (30.8\%) dominant occurred in group with small diastema $(\leq 2 \mathrm{~mm})$. However in the group with large diastema no mucosal type was observed and only $19.2 \%$ with gingival type of attachment. Large diastemas (> $2 \mathrm{~mm}$ ) were characterised by papillary (III) type (34.6\%) and papilla penetrating (IV) type of frenulum attachment (Fig. 3).
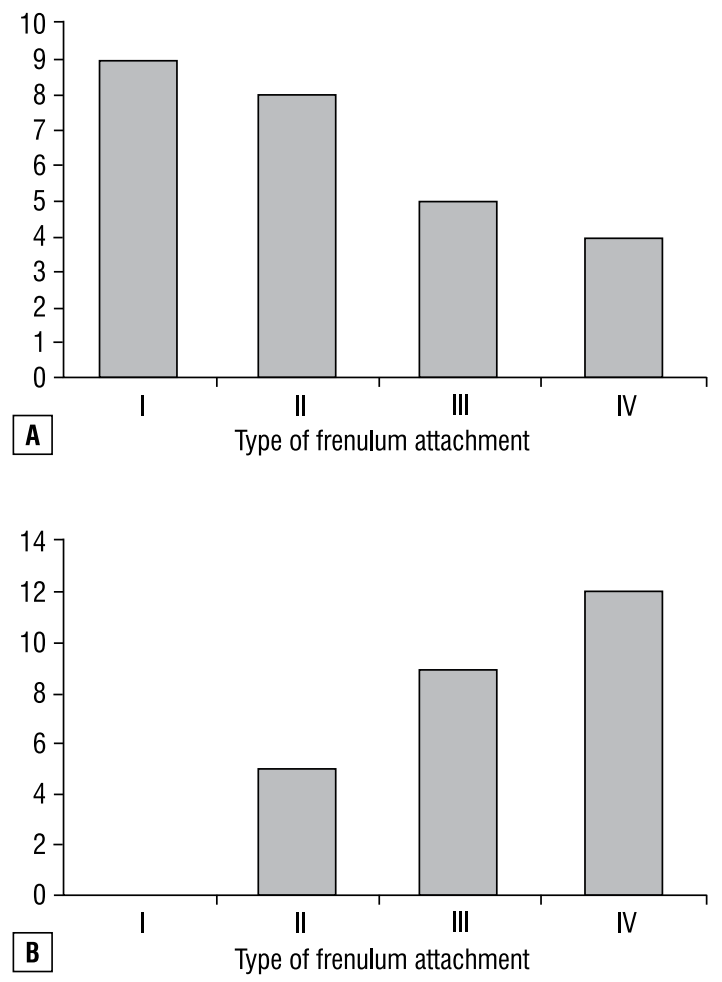

Figure 3. Type of frenulum in different sizes of diastema, A. Diastema $\leq 2 \mathrm{~mm}$; B. Diastema $>2 \mathrm{~mm}$.

Clinical documentation of patients with different size of diastema and different type of frenulum are additionally presented on Figure 4.

\section{DISCUSSION}

Aesthetic appearance is very important nowadays. Some studies suggest that people with nice appearance have a higher self-esteem; they are seen 


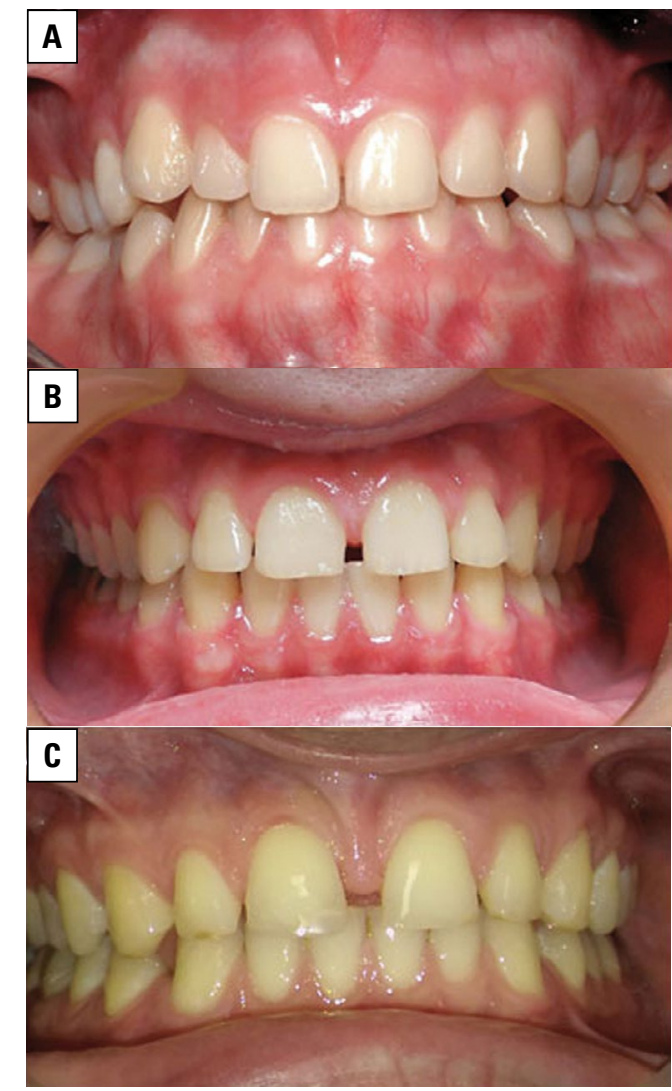

Figure 4. Three different sizes of diastema and upper lip frenulum attachments; A. Small diastema $\leq 1 \mathrm{~mm}$. Mucosal frenulum attachment; B. Medium diastema $>1 \leq 2 \mathrm{~mm}$. Gingival frenulum attachment; C. Large diastema $>2 \mathrm{~mm}$. Papilla penetrating frenulum attachment.

as smarter and more prosperous; they get better notes on exams and can easier find life partners $[5,20,30,36]$. Also smile appearance is important. All over the world women more often were dental and orthodontic patients then men. Although female dental problems were often milder then male but their treatment needs were higher $[9,16,23]$. In investigated material also women were prevailing over man, which is similar as in other publications.

Opinions on smile aesthetics in patients with diastema are divided. For some people diastema is a characteristic feature of smile; others think that diastema is a cosmetic defect. The most important is the size of diastema. In the study group the most patients had diastema bigger than $2 \mathrm{~mm}$ and they constituted half of all patients with diastema. This 2-mm width of diastema is the most often regarded as an aesthetic limit of smile attractiveness and is negatively assessed by other people and the unfavourably affects self-esteem of patients [22, 24]. Also, diastema $>1 \mathrm{~mm}$ was indicated in some papers as a defect that required correction [21, 36]. In the present study diastema bigger than $1 \mathrm{~mm}$ was also often observed (38.5\%). According to the present study, diastema of more than $2 \mathrm{~mm}$ was the most frequent, but also diastema bigger than $1 \mathrm{~mm}$ was a problem and a frequent cause of reporting to the dental office.

In many publications the impact of oversized upper lip frenulum on the formation of diastema was described $[2,15,17,18,27]$. These reports are consistent with our research. Large frenulum attachment classified as type III (papillary) or IV (penetrating to the papilla) by Placek et al. [29] significantly more often (57.7\%) occurred in patients with diastema. In the group of people without diastema only in $2 \%$ of the III type (papillary) frenulum and no type IV (penetrating to the papilla) were observed. In addition, some researchers found that patients with oversized frenulum had bigger diastema, than patients with normal frenulum $[4,31]$. Similar results to those presented in the literature were obtained in our study. The type of frenulum has an impact on the width of the diastema. In group of patients with small diastema $\leq 2 \mathrm{~mm}$ mucosal and gingival type of frenulum (65.4\%) prevailed. Large diastema $>2 \mathrm{~mm}$ coexisted with oversized type III (papillary) and IV (penetrating to the papilla) frenulum, which was found in $80.8 \%$ of patients. There was no I type (mucosal) frenulum in those with large diastema.

Enlarge upper lip frenulum caused clinical problems $[14,15]$. Besides diastema, overgrown frenulum may hinder brushing teeth and cause caries of upper central incisors especially in children [35]. Also periodontal problems could be caused by enlarged frenulum, especially in cases when pulling the upper lip caused moving and blanching tissue between the central incisors, what entail gums recessions in the future $[18,35]$. During orthodontic, but also restorative treatment, of diastema large frenulum prevents closure of diastema and could cause relapse of diastema $[25,26]$. In those cases a surgical intervention is needed [18, 32].

\section{CONCLUSIONS}

Patients with diastema have more often oversized upper lip frenulum attachment then patient without diastema.

The most often type of frenulum in patients with diastema is papillary and papilla penetrating type.

The size of diastema depends on type of upper lip frenulum attachment. For small diastema $(\leq 2 \mathrm{~mm})$ mucosal and gingival type is characteristic. Papillary and papilla penetrating type of frenulum coexisted with large diastema ( $>2 \mathrm{~mm}$ ). 


\section{REFERENCES}

1. Andrews LF. The six keys to normal occlusion. Am J Orthod. 1972; 62(3): 296-309, indexed in Pubmed: 4505873.

2. Attia Y. Midline diastemas: closure and stability. Angle Orthod. 1993; 63(3): 209-212, doi: 10.1043/0003 -3219(1993)063<0209:MDCAS>2.0.CO;2, indexed in Pubmed: 8214789.

3. Bednarz W, Bednarz B. Zabieg frenulektomii częścią periodontologiczno-ortodontycznego leczenia diastemy prawdziwej. Mag Stomatol. 2014; 24: 20-26.

4. Bednarz W, Sokołowski B. Kompleks śluzówkowo-dziąsłowy w wieku rozwojowym. e-Dentico. 2007; 1: 58-64.

5. Bernabé $\mathrm{E}$, Flores-Mir C. Influence of anterior occlusal characteristics on self-perceived dental appearance in young adults. Angle Orthod. 2007; 77(5): 831-836, doi: 10.2319/082506-348.1, indexed in Pubmed: 17685776.

6. Bhattacharya P, Raju PS, Bajpai A. Prognosis v/s etiology: midline papilla reconstruction after closure of median diastema. Ann Essences Dent. 2011; 3(1): 37-40, doi: 10.5368/aedj.2011.3.1.1.7.

7. Björk A, Krebs A, Solow B. A method for epidemiological registration of malocclusion. Acta Odontol Scand. 1964; 22: 27-41, indexed in Pubmed: 14158468.

8. Brunelle JA, Bhat M, Lipton JA. Prevalence and distribution of selected occlusal characteristics in the US population, 1988-1991. J Dent Res. 1996; 75 Spec No: 706-713, doi: 10.1177/002203459607502S10, indexed in Pubmed: 8594094.

9. Choi SH, Kim JS, Cha JY, et al. Effect of malocclusion severity on oral health-related quality of life and food intake ability in a Korean population. Am J Orthod Dentofacial Orthop. 2016; 149(3): 384-390, doi: 10.1016/j.ajodo.2015.08.019, indexed in Pubmed: 26926026.

10. Chu $\mathrm{CH}$, Zhang $\mathrm{CF}$, Jin $\amalg$. Treating a maxillary midline diastema in adult patients: a general dentist's perspective. J Am Dent Assoc. 2011; 142(11): 1258-1264, indexed in Pubmed: 22041411.

11. Delli $K$, Livas $C$, Sculean A, et al. Facts and myths regarding the maxillary midline frenum and its treatment: a systematic review of the literature. Quintessence Int. 2013; 44(2): 177-187, doi: 10.3290/j. qi.a28925, indexed in Pubmed: 23444184.

12. Díaz-Pizán ME, Lagravère MO, Villena R. Midline diastema and frenum morphology in the primary dentition. J Dent Child (Chic). 2006; 73(1): 11-14, indexed in Pubmed: 16734307.

13. España P, Tarazona B, Paredes V. Smile esthetics from odontology students' perspectives. Angle Orthod. 2014; 84(2): 214-224, doi: 10.2319/032013-226.1, indexed in Pubmed: 23924403.

14. Farronato G, Salvadori S, Giannini L, et al. Congenital macroglossia: surgical and orthodontic management. Prog Orthod. 2012; 13(1): 92-98, doi: 10.1016/j.pio.2011.06.003, indexed in Pubmed: 22583592.

15. Gkantidis N, Kolokitha OE, Topouzelis N. Management of maxillary midline diastema with emphasis on etiology. J Clin Pediatr Dent. 2008; 32(4): 265-272, indexed in Pubmed: 18767455.

16. Harris EF, Glassell BE. Sex differences in the uptake of orthodontic services among adolescents in the United States. Am J Orthod Dentofacial Orthop. 2011; 140(4): 543-549, doi: 10.1016/j. ajodo.2010.11.023, indexed in Pubmed: 21967943.

17. Huang WJ, Creath CJ. The midline diastema: a review of its etiology and treatment. Pediatr Dent. 1995; 17(3): 171-179, indexed in Pubmed: 7617490 .

18. Joneja $P$, Pal V, Tiwari $M$, et al. Factors to be considered in treatment of midline diastema. Int J Curr Pharm Res. 2013; 5: 1-3.

19. Kadouch DJM, Maas SM, Dubois L, et al. Surgical treatment of macroglossia in patients with Beckwith-Wiedemann syndrome: a 20-year experience and review of the literature. Int J Oral Maxillofac Surg. 2012; 41(3): 300-308, doi: 10.1016/j.ijom.2011.10.021, indexed in Pubmed: 22104000.
20. Kerosuo $\mathrm{H}$, Hausen $\mathrm{H}$, Laine $\mathrm{T}$, et al. The influence of incisal malocclusion on the social attractiveness of young adults in Finland. Eur J Orthod. 1995; 17(6): 505-512, indexed in Pubmed: 8682167.

21. Kokich VO, Kokich VG, Kiyak HA. Perceptions of dental professionals and laypersons to altered dental esthetics: asymmetric and symmetric situations. Am J Orthod Dentofacial Orthop. 2006; 130(2): 141-151, doi: 10.1016/j.ajodo.2006.04.017, indexed in Pubmed: 16905057.

22. Korkut B, Yanikoglu F, Tagtekin D. Direct midline diastema closure with composite layering technique: a one-year follow-up. Case Rep Dent. 2016; 2016: 6810984, doi: 10.1155/2016/6810984, indexed in Pubmed: 26881147.

23. Krooks L, Pirttiniemi P, Kanavakis G, et al. Prevalence of malocclusion traits and orthodontic treatment in a Finnish adult population. Acta Odontol Scand. 2016; 74(5): 362-367, doi: 10.3109/00016357.20 16.1151547, indexed in Pubmed: 26940248.

24. Marques LS, Filogônio CA, Filogônio CB, et al. Aesthetic impact of malocclusion in the daily living of Brazilian adolescents. J Orthod. 2009; 36(3): 152-159, doi: 10.1179/14653120723139, indexed in Pubmed: 19741176.

25. Mattos $C T$, da Silva DL, Ruellas AC. Relapse of a maxillary median diastema: closure and permanent retention. Am J Orthod Dentofacial Orthop. 2012; 141(1): e23-e27, doi: 10.1016/j.ajodo.2011.05.022, indexed in Pubmed: 22196198.

26. Moffitt $A H$, Raina J. Long-term bonded retention after closure of maxillary midline diastema. Am J Orthod Dentofacial Orthop. 2015; 148(2): 238-244, doi: 10.1016/j.ajodo.2015.03.026, indexed in Pubmed: 26232832.

27. Oesterle $\sqcup$, Shellhart WC. Maxillary midline diastemas: a look at the causes. J Am Dent Assoc. 1999; 130(1): 85-94, indexed in Pubmed: 9919036.

28. Onyeaso C. Prevalence of malocclusion among adolescents in Ibadan, Nigeria. Am J Orthod Dentofac Orthop. 2004; 126(5): 604-607, doi: 10.1016/j.ajodo.2003.07.012.

29. Placek M, Skach M, Lubor M. Significance of the Labial Frenum Attachment in Periodontal Disease in Man. Part 1. Classification and Epidemiology of the Labial Frenum Attachment. J Periodontol. 1974; 45(12): 891-894, doi: 10.1902/jop.1974.45.12.891.

30. Scapini A, Feldens CA, Ardenghi TM, et al. Malocclusion impacts adolescents' oral health-related quality of life. Angle Orthod. 2013; 83(3): 512-518, doi: 10.2319/062012-509.1, indexed in Pubmed: 23210545.

31. Shashua D, Artun J. Relapse after orthodontic correction of maxillary median diastema: a follow-up evaluation of consecutive cases. Angle Orthod. 1999; 69(3): 257-263, doi: 10.1043/0003-3219(1999)069<0257:RAOCOM>2.3.CO;2, indexed in Pubmed: 10371432.

32. Sullivan TC, Turpin DL, Artun J. A postretention study of patients presenting with a maxillary median diastema. Angle Orthod. 1996; 66(2): 131-138, doi: 10.1043/0003-3219(1996)066<0131:APSOPP >2.3.CO;2, indexed in Pubmed: 8712491.

33. Thilander B, Pena L, Infante $C$, et al. Prevalence of malocclusion and orthodontic treatment need in children and adolescents in Bogota, Colombia. An epidemiological study related to different stages of dental development. Eur J Orthod. 2001; 23(2): 153-167, indexed in Pubmed: 11398553.

34. Tyrologou S, Koch G, Kurol J. Location, complications and treatment of mesiodentes--a retrospective study in children. Swed Dent J. 2005; 29(1): 1-9, indexed in Pubmed: 15898358.

35. Wacińska Dr, Zadurska M, Zwierzchowska H. Wędzidełka wargi górnej - w aspekcie ortodoncji, periodontologii, protetyki i estetyki. Nowa Stom. 2007; 12: 134-138.

36. Witt M, Flores-Mir C. Laypeople's preferences regarding frontal dentofacial esthetics. J Am Dent Assoc. 2011; 142(6): 635-645, doi: 10.14219/jada.archive.2011.0245. 